\title{
26. COMPARATIVE LOGGING RESULTS IN CLAY-RICH LITHOLOGIES ON THE BARBADOS RIDGE ${ }^{1}$
}

\author{
M.J. Jurado, ${ }^{2}$ J.C. Moore ${ }^{3}$ and D. Goldberg ${ }^{4}$
}

\begin{abstract}
Logging-while-drilling (LWD) data and open-hole wireline logs were acquired during Ocean Drilling Program Leg 156 in the Barbados accretionary prism, through the décollement, and into the underthrusting plate. Analysis of the LWD data indicates that the logs are suitable for qualitative and quantitative interpretations, whereas the quality of the wireline logs was adversely affected by poor hole conditions during acquisition. Inversion on LWD data provide porosity and compositional models for the Leg 156 sites. A key question addressed is the effect of compositional and bound water on porosity estimates. The combined analysis performed on Hole 948A LWD density and neutron porosity logs and natural gamma-ray spectral data is used to study the effect of compositional and bound water from the log response. We found a qualitative correlation between LWD log response, physical property measurements, and compositional changes derived from cores. LWD data also reflect the main tectonic and stratigraphic features recognized at Site 948 and allow identification of similar features at Site 947.
\end{abstract}

\section{INTRODUCTION}

Logging-while-drilling (LWD) data acquired during Ocean Drilling Program (ODP) Leg 156 are analyzed to evaluate the log data quality, the effect of porosity and composition of the clay-rich sediments, the correspondence between LWD data and available core physical property measurements, and to identify the main geological features on the basis of the $\log$ response.

The primary scientific objective of ODP Leg 156 was the investigation of fluid flow, fluid pressure, and permeability of the décollement zone by drilling and logging through the intensively deformed sediments and high fluid pressures associated with the faults (G.F. Moore et al., 1995; J.C. Moore et al., 1995). The acquisition of a set of geophysical logs through the northern Barbados Ridge accretionary prism, the décollement zone, and into the uppermost part of the underthrusting portion of the North American Plate, was one of the important achievements of Leg 156 (Shipley, Ogawa, Blum, et al., 1995). Logging with conventional open-hole wireline tools during previous legs (Mascle, Moore, et al., 1988) proved unsuccessful in such an unstable environment. The use of open-hole wireline logging tools in Hole 948C confirmed the difficulty of obtaining results in this area with conventional technologies. Application of the LWD technology, utilized for the first time in scientific drilling, allowed successful logging of Holes 947A and 948A (Figs. 1, 2). Additional borehole measurements at these sites included vertical seismic profiling (VSP) in cased holes at Sites 948 and 949, which provided an accurate correlation between the drilled section and three-dimensional seismic reflection profiling (Shipley, Ogawa, Blum, et al., 1995; Moore et al., Chapter 20, this volume).

During Leg 156, the LWD data were acquired through both a Miocene to recent, poorly lithified accretionary prism section, and the Miocene and upper Oligocene sediments of the underthrusting

${ }^{1}$ Shipley, T.H., Ogawa, Y., Blum, P., and Bahr, J.M. (Eds.), 1997. Proc. ODP, Sci. Results, 156: College Station. TX (Ocean Drilling Program).

${ }^{2}$ Geophysikalisches Institut, Universität Fridericiana Karlsruhe, Hertzstrasse 16, 76187 Karlsruhe, Federal Republic of Germany.

mjjurado@gpiwap1.physik.uni-karlsruhe.de

${ }^{3}$ Earth Sciences Department, University of California, Santa Cruz, Santa Cruz, CA 95064, U.S.A.

${ }^{4}$ Borehole Research Group, Lamont Doherty Earth Observatory, Columbia University, Palisades, NY 10964, U.S.A. plate. Claystones of varying composition (variable amounts of the different clay minerals and carbonate, quartz, and plagioclase content) were recognized during previous ODP and Deep Sea Drilling Project (DSDP) legs as the primary sediments in the accretionary prism and the uppermost underthrusting plate. The logging data acquired during Leg 156 provide the first continuous record of a complete set of physical properties across the décollement. The LWD data have also been used in several other studies to investigate the composition and porosity variations in the Barbados accretionary prism (e.g. Shipley, Ogawa, Blum, et al., 1995; J.C. Moore et al., 1995; Jurado and Alonso, Chapter 16, this volume; Tobin and Moore, Chapter 9, this volume; Moore et al., Chapter 20, this volume; Saito and Goldberg, 1997).

\section{LWD AND WIRELINE LOGS: DATA QUALITY AND OPERATIONS}

Log data were recorded in Holes 947A and 948A using the Schlumberger LWD, compensated dual resistivity (CDR) and compensated density neutron (CDN) tools. Although these differ from the standard wireline logging tools, similar results are obtained as established by comparative studies when functioning under optimal acquisition conditions (Desbrandes, 1994). A full description of the principles and measurements performed by these tools is given by Schlumberger Educational Services (1992) and Desbrandes (1994). Holes $947 \mathrm{~A}$ and $948 \mathrm{~A}$ were successfully logged with both the CDR and CDN tools, and the data are considered to be of overall good quality (Shipley, Ogawa, Blum, et al., 1995).

\section{LWD Log Descriptions}

The vertical resolution for the logging data acquired with the CDR and CDN tools is between 20 and $61 \mathrm{~cm}$ for natural spectral gamma-ray data (SGR), $15.7 \mathrm{~cm}$ for the formation bulk density logs (RHOB), $5 \mathrm{~cm}$ for the photoelectric effect $\log$ (PEF), $15 \mathrm{~cm}$ for the resistivity logs (ATR and PSR), and $33.5 \mathrm{~cm}$ for the neutron porosity $\log$ (TNPH) (Schlumberger Educational Services, 1992).

In spectral gamma-ray logging, the radiation level is measured in several energy windows. SGR responds to the presence of radioactive elements in the formation. THOR, URAN, and POTA logs represent the contribution of thorium, uranium, and potassium to the to- 
Figure 1. Leg 156 study area and seismic profile showing the location of Leg 156 Sites 947 and 948 and Leg 110 Site 671. LWD gamma-ray (left) and density (right) curves represented at Sites 947 and 948.
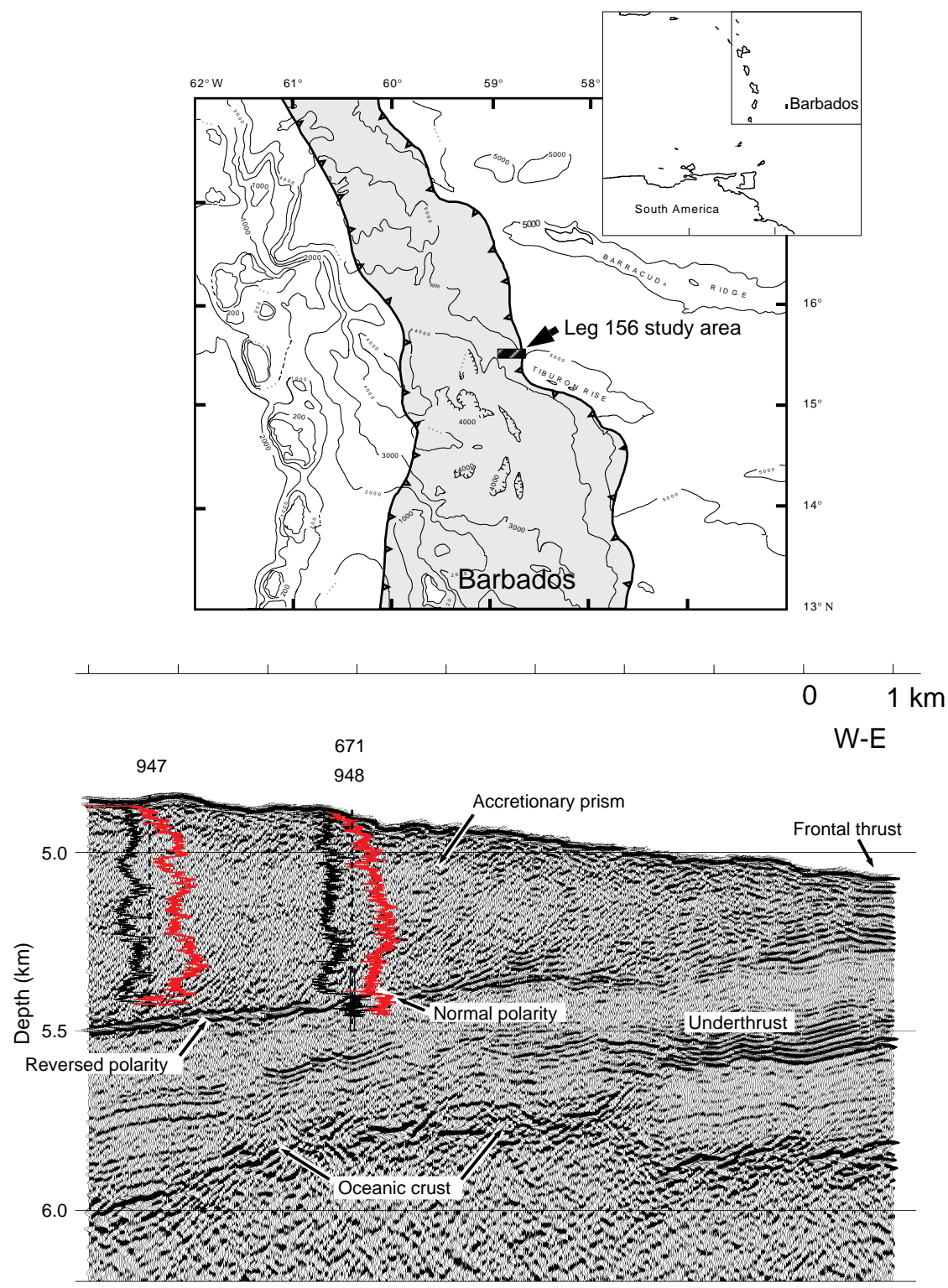

tal gamma-ray count recorded by the spectral gamma-ray tool. The individual contributions of the three elements in relation to the total formation weight are calculated from the energy spectra. The statistical methods applied to estimate the Th, $\mathrm{U}$, and $\mathrm{K}$ quantities is fully described by Schlumberger (1987). CGR is the computed natural gamma-ray logging tool (GR) count of the spectral gamma-ray measurement, excluding the uranium count.

RHOB corresponds to a reading of the bulk formation density and responds primarily to the rock composition and to the porosity of the formation. PEF indicates the absorption of a low-energy gamma resulting from ejection of a low orbital electron from its orbit, and responds primarily to rock composition. ATR and PSR are two depths of investigation of the formation resistivity with the CDR tool. PSR resistivity provides a shallow depth of investigation, whereas ATR provides a deeper depth of investigation. These CDR formation resistivity measurements are most accurate in low-resistivity formations (below $2 \Omega \mathrm{m}$; Schlumberger Educational Services, 1992), such as those intersected at Holes 947A and 948A. TNPH, the neutron porosity, responds to rock composition and hydrogen content.

Figure 2 shows the set of LWD measurements for Holes 947A and 948A. Only LWD data were acquired at Site 947. The décollement was penetrated in Site 948 (498-529 m below seafloor [mbsf]; Hous- en et al., 1996; Shipley, Ogawa, Blum, et al. 1995); drilling difficulties caused by high pressures and hole instability prevented LWD through the décollement at Hole 947A.

In this first ODP experience with the LWD technology, careful coordination of drilling operations was required to produce optimal logging conditions. It is difficult to maintain the appropriate drilling rate of penetration (ROP) in soft sediments, with ship heave being an additional uncertainty introduced in the LWD data acquisition on JOIDES Resolution. For both Holes 947A and 948A, the ROP was on average $\sim 50 \mathrm{~m} / \mathrm{hr}$ over the entire section. In both cases, the logging speed in the uppermost section $(0-55 \mathrm{~m}$ below sea floor, [mbsf] in Hole 947A and 0-45 mbsf in Hole 948A) was 2 to 4 times higher. Other intervals where the ROP reached more than $100 \mathrm{~m} / \mathrm{hr}$ are between 385 and 448 mbsf at Hole 947A, and between 170 and 190 mbsf and below 525 mbsf at Hole 948A. The ROP recorded (Fig. 2, first track) was above the recommended rates for spectral gamma-ray acquisition (between 15 and $20 \mathrm{~m} / \mathrm{hr}$ ) and not constant. The analysis of the LWD data presented in Figure 2, however, suggests good LWD data quality. In particular, gamma-ray logging requires a time constant to optimize the effect of the statistical variations of the radioactivity emission; therefore, it is the most sensitive LWD log to logging speed. Nevertheless, in Figure 2 it appears that the LWD 


\section{Hole 947A LWD logs}

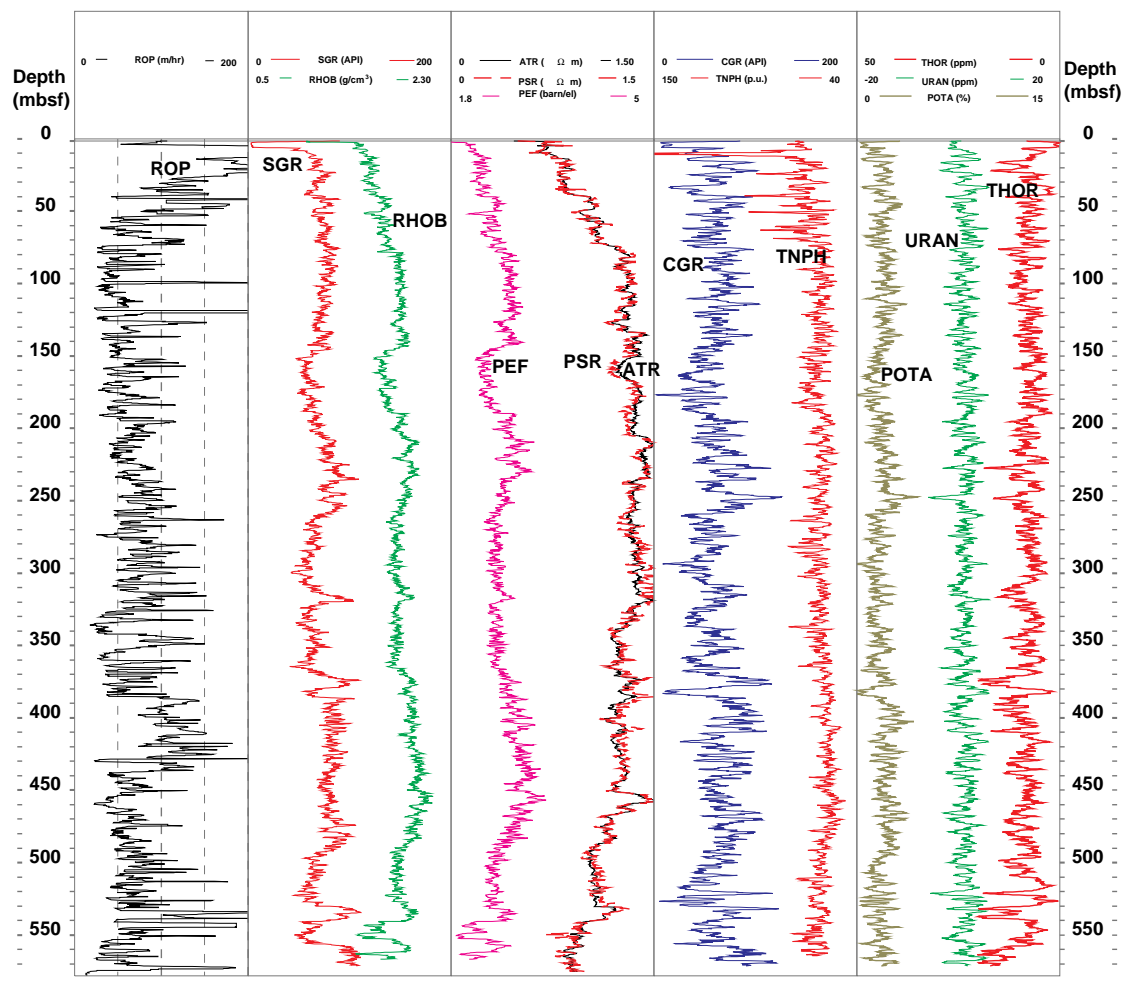

Hole 948A LWD logs

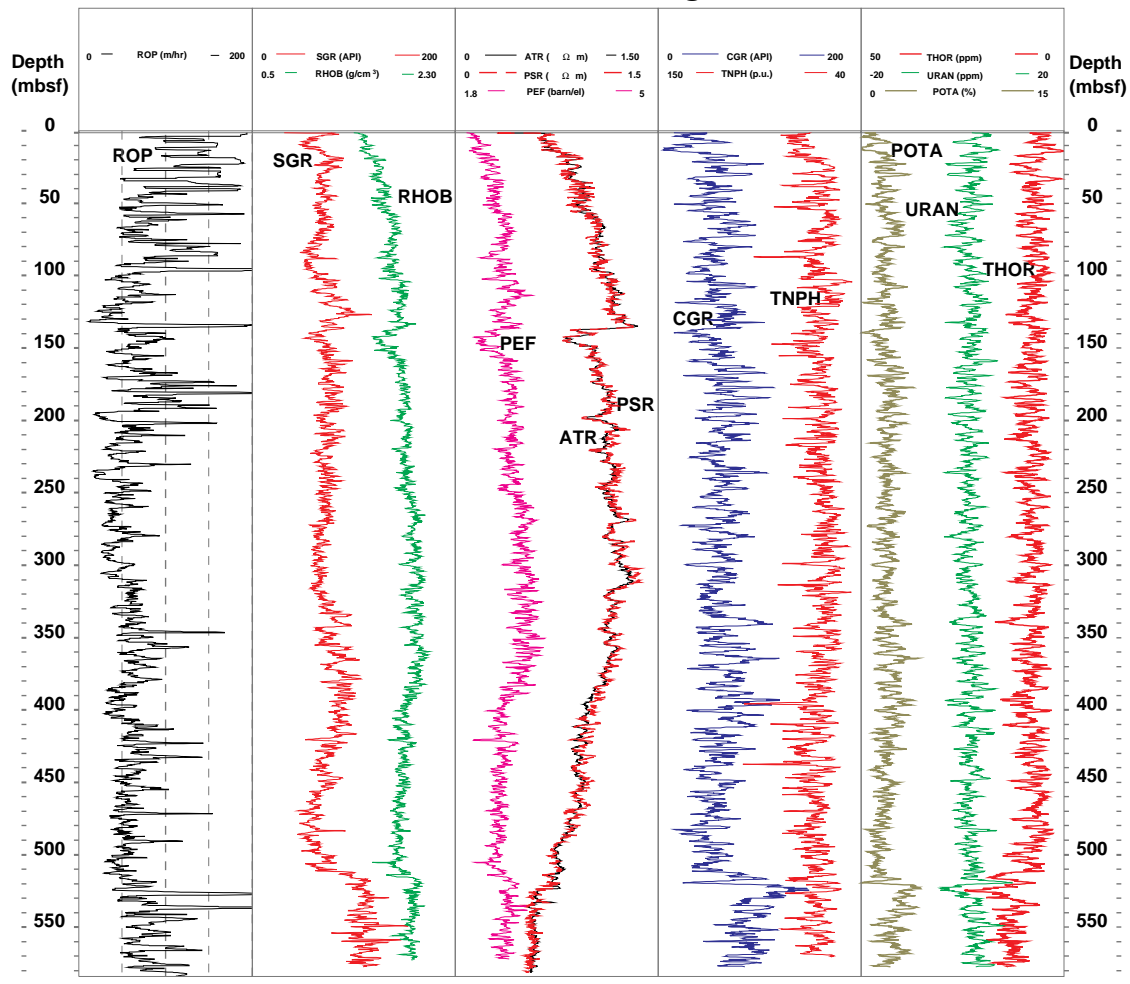

Figure 2. Hole 947A and Hole 948A LWD logs. The rate of penetration (ROP) is in track 1 , total natural spectral gamma ray (SGR) and formation bulk density (RHOB) are in track 2, shipboard photoelectric effect (PEF) and resistivity logs (ATR, PSR) are in track 3 , computed uranium-free gamma-ray and apparent neutron porosity (TNPH) logs are in track 4 , and spectral natural gamma thorium (THOR), uranium (URAN), and potassium (POTA) logs are in track 5 . gamma-ray data are not significantly degraded by the logging speed. There is no sign of a direct correlation between the ROP and the log responses. With a fast logging speed, the shape of the beds would be distorted, and the natural gamma counts would not be fully recorded. In intervals where abrupt changes in ROP occur, such as 385-448 mbsf in Hole 947A, changes observed in the log character do not cor- relate with changes in ROP. There is no corresponding decrease in the log values in any of the logging data, except for some correlation between logging speed and log response of the CGR and TNPH curves. These correlations suggest that the logs primarily represent changes in formation properties, which also affect the ease of penetration. The log values recorded are within the range expected for 
these sediments and correlate reasonably well with physical properties measurements. The log trends match the described lithostratigraphy at Site 948 (Shipley, Ogawa, Blum, et al., 1995). These observations regarding the LWD data suggest that they may be used qualitatively and quantitatively for composition and porosity estimation.

A further confirmation of LWD reliability comes from the acquisition of repeated runs over the same depth interval. As is done routinely for quality control in wireline log acquisition, repeated sections were obtained over a "backreamed" interval from 550 to $500 \mathrm{mbsf}$. For the Hole 947A repeated section (499-529 mbsf), the resistivity values are almost coincident, and natural radioactivity and neutron porosity readings are similar. Density values are on the order of 0.165 $\mathrm{g} / \mathrm{cm}^{3}$ lower in the repeated section. In all cases, the log curves show the same increasing-decreasing trends for the same depths. The repeated run for Hole 948A (460-530 mbsf) shows similar values for the resistivity log and disagreement for the natural gamma ray. Neutron porosity values are higher and density values are lower (from 0.33 to $0.02 \mathrm{~g} / \mathrm{cm}^{3}$ ) than in the main run. It must be kept in mind, however, that the environmental conditions existing "while drilling" are unrepeatable over the same depth interval, as the hole must essentially be redrilled.

Once coring operations were completed at Hole 948C, open-hole logs were acquired with the long spacing sonic tool (LSS), high temperature lithodensity tool (HLDT), and natural gamma-ray spectrometry tool (NGT) logging string. The caliper data recorded with the HLDT tool caliper indicate bad hole conditions that resulted in tool sticking and bad readings related to hole enlargement (Fig. 3). Hole conditions, therefore, considerably affected the data quality. The caliper was restricted from $\sim 525$ to 330 mbsf because of severe collapse of the hole. The small-diameter caliper measurements near $500 \mathrm{mbsf}$ at the décollement zone correlate with high wire tension. These observations suggest that sediment of the décollement zone was selectively extruding into the borehole. Hole 948C NGT data were corrected for borehole size and drilling fluid, and acoustic LSS data (sonic logs) were corrected for cycle skipping during shore-based processing at Lamont-Doherty Earth Observatory Borehole Research Group. Borehole irregularity affected the overall data quality and especially the density log data (Fig. 3).

\section{INVERSION OF LWD DATA: POROSITY AND COMPOSITION}

Most of the measurements recorded with the CDN and CDR tools are suitable for application in quantitative formation evaluation (Desbrandes, 1994). The log responses are related to the rock composition and fluids. The problem of deriving composition and porosity from Leg 156 logging data (and also from the core data) becomes complex because different clay minerals with a variety of physical properties are involved. For example, log density values can range from $2.12 \mathrm{~g} / \mathrm{cm}^{3}$ (smectite) to $2.76 \mathrm{~g} / \mathrm{cm}^{3}$ (chlorite). One clay-type density may be as different from another as it is from feldspar, calcite, or quartz, which are the other mineral components present in the sediments analyzed (Shipley, Ogawa, Blum, et al., 1995; Fisher and Underwood, 1995; Jurado and Alonso, Chapter 16, this volume; Underwood and Deng, Chapter 1, this volume).

\section{Porosity Inversion}

An accurate porosity analysis requires that the mineral composition is well characterized. To calculate porosity from log-derived bulk density, it is necessary to know the density of all the individual materials involved. In the absence of an accurate and continuous profile of the mineralogical composition of the sediments, the inversion of porosity from the log-derived bulk density provides a fast quantitative estimation of the formation porosity by solving for each depth point the following equation:

$$
\Phi=\left(\rho_{m a}-\rho_{b}\right) /\left(\rho_{m a}-\rho_{f}\right),
$$

where $\rho_{m a}=$ matrix or grain density; $\rho_{f}=$ fluid density; and $\rho_{b}=$ bulk density measured by the tool (includes porosity and grain density).

Applying a uniform grain density value to derive porosity from the density log when the grain density is not constant may yield inaccurate porosities (Rider, 1986). Changing fluid densities can also be a source of inaccuracy. When a too high grain density or too high fluid density is used, the porosity is overestimated and vice versa.

The first inversion model from the LWD data was obtained to produce a porosity profile from the density log by using Site 671 average grain density values (Shipley, Ogawa, Blum, et al., 1995; J.C. Moore et al., 1995). The porosity values were then used to predict a fluid pressure profile (J.C. Moore et al., 1995; Tobin and Moore, Chapter 9, this volume). As pointed out by Henry (Chapter 10, this volume), applying different grain densities to Site 948 LWD data does not introduce major changes in the porosity calculation. Figure 4 shows the porosity profiles obtained from the inversion of the density log, applying different grain densities. The grain-density values used in this test correspond to a commonly used "averaged value" for shaly sediments, $2.65 \mathrm{~g} / \mathrm{cm}^{3}$; averaged Hole 671B core-measured grain densities were at $2.73 \mathrm{~g} / \mathrm{cm}^{3}$ (Shipley, Ogawa, Blum, et al., 1995), and a standard grain-density value for smectite was $2.88 \mathrm{~g} / \mathrm{cm}^{3}$ (Serra, 1986). The fluid density was $1.09 \mathrm{~g} / \mathrm{cm}^{3}$ in all three cases. The average value of the calculated porosities for the interval $0-570 \mathrm{mbsf}$ are $52.5 \%$ porosity for $2.65 \mathrm{~g} / \mathrm{cm}^{3}, 54.8 \%$ porosity for $2.73 \mathrm{~g} / \mathrm{cm}^{3}$, and $58.6 \%$ porosity for $2.88 \mathrm{~g} / \mathrm{cm}^{3}$. As suggested by recent studies (Henry, Chapter 10, this volume), if grain densities are slightly higher than those measured shipboard, the calculated density porosity would be slightly higher that those obtained in previous studies.

Total porosity is the volumetric proportion of free-water (or fluid) content. In the case of clays, defining and measuring the "free water" is difficult. Water is present in claystones as (1) free water, (2) bound water, and (3) compositional (lattice) water. Density and neutron logging tools detect free and adsorbed water, but only the neutron tool is capable of detecting the compositional water because it is sensitive to all the hydroxyl groups present in the formation. Whereas the density $\log$ records bulk density, the neutron log measures the hydrogen content; both sense the free water in the pore space as porosity. However, the neutron log will yield a higher porosity because it also recognizes those hydroxyl ions bound in the crystal lattice, in addition to those hydrogen atoms of the pore water. Consequently, variations in the disagreement between the density and neutron log responses are mainly due to the volume and type of clays present (Ruhovets and Fertl, 1981).

Clay minerals fall into two categories differentiated by significantly different hydrogen index (HI) values; those of high $\mathrm{HI}$ and those of low HI. Chlorite and kaolinite have a HI of $0.36-0.38$, whereas both illite and smectite have a HI of 0.12-0.13 (Ruhovets and Fertl, 1981). Chlorite and kaolinite produce a significant discrepancy between the density and neutron logs. Smectites and illites cause considerably less disagreement. Conversely, clay minerals with low HI, particularly smectites, usually have a substantially greater amount of bound water than the clays with high HI. Neutron porosity readings in illite are lower than for the other three clay types, whereas the corresponding density log-derived porosity should be lower than that in smectite, but higher than that in chlorite and kaolinite.

Magara (1979) and Honda and Magara (1982) approach the "bound water and porosity" discrepancy in mudstones in a manner that is applicable to this case. The adsorbed and free water are detected as porosity by both the density and the neutron tools. Bound water, however, is detected only by the neutron tool.

Figure 4 compares the density-porosity relationship calculated for Hole $948 \mathrm{~A}$ (assuming $\rho_{m a}=2.73 \mathrm{~g} / \mathrm{cm}^{3}, \rho_{f}=1.09 \mathrm{~g} / \mathrm{cm}^{3}$ ) and the neutron log scaled in apparent neutron porosity units. The separation between the density and the neutron porosity logs (density porosity sub- 


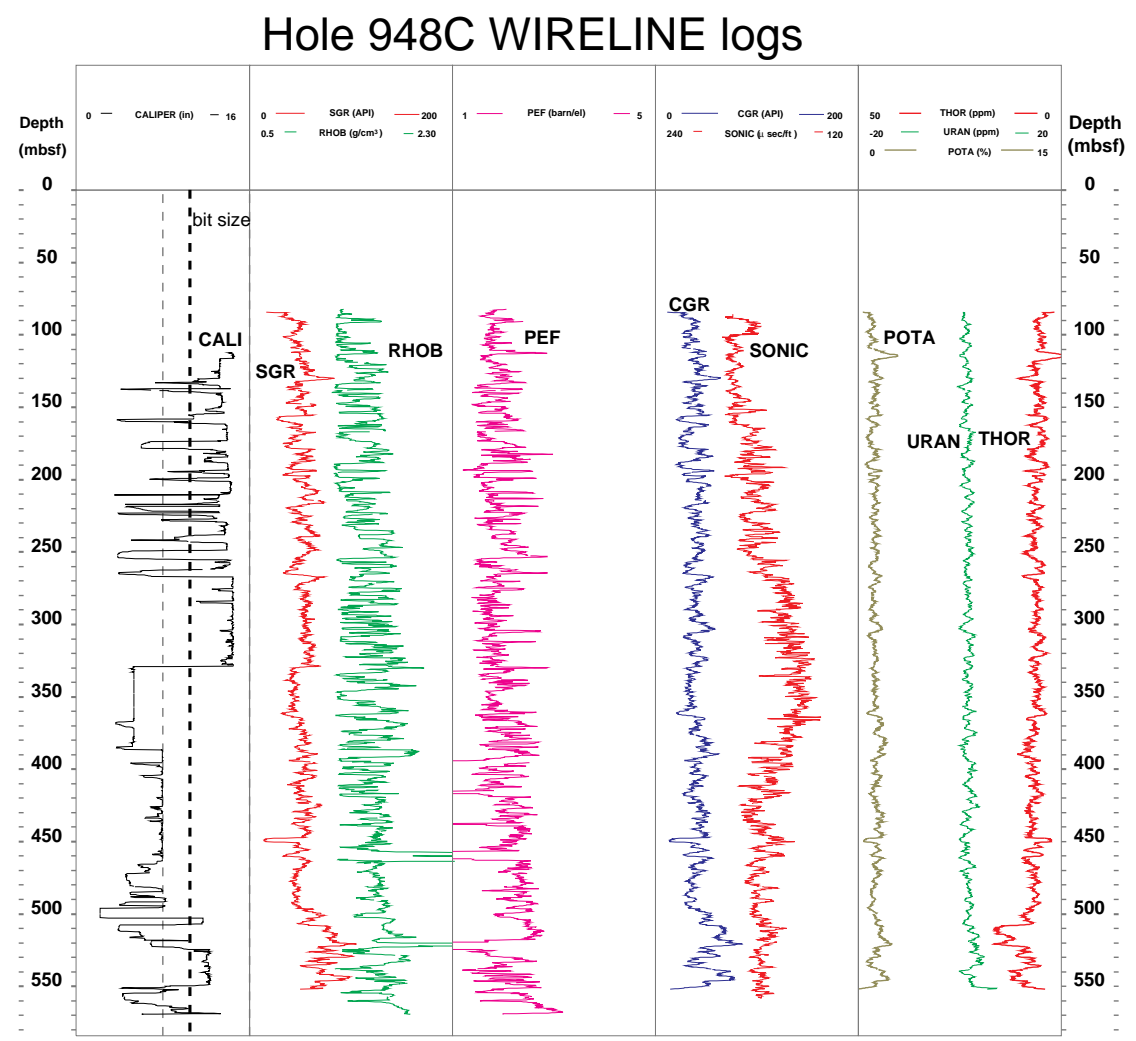

Figure 3. Hole 948C open-hole wireline logs. The borehole caliper (CALI) is in track 1, total natural spectral gamma ray and formation bulk density are in track 2, photoelectric effect is in track 3, computed uranium-free gamma ray and sonic log (SONIC) $\operatorname{logs}$ are in track 4, and the spectral natural gamma thorium, uranium, and potassium logs are in track 5 . tracted from apparent neutron porosity, rightmost track) is small within the uppermost $150 \mathrm{~m}$, but increases downhole to $\sim 385 \mathrm{mbsf}$. This occurs because the density porosity decreases more rapidly than the neutron porosity decreases. At $\sim 385 \mathrm{mbsf}$, the density porosity curve trends towards higher values. Between 385 and 508 mbsf, an increase in the calculated density porosity and a moderate increase in the neutron porosity results in a small separation between the porosity curves. The intervals of greatest separation within the accretionary prism sediments occur between 395 and 399 mbsf, and also between 517 and 519 mbsf. The separation within the underthrusting Oligocene sediments is greater because of the considerable decrease in the density porosity and the simultaneous small decrease in neutron porosity.

The changes and trends observed on the logging data are, in this case, the result of the complex combined effects of rock composition and water content. The spectral gamma-ray thorium/potassium ratio $(\mathrm{Th} / \mathrm{K})$ is commonly applied to determine the clay type in shales and is considered a function of mineralogical composition (Quirein et al., 1982; Schlumberger, 1983; Ellis, 1987). The $\mathrm{Th} / \mathrm{K}$ value is $\sim 10$ for smectite, 20 for kaolinite, and $\sim 4$ for illite. Clays are the major component of these sediments as stated for Holes 671B (Tribble, 1990) and 948C (Fisher and Underwood, 1995). Noticeable variations in the $\mathrm{Th} / \mathrm{K}$ trace indicate changes in clay mineralogy composition. The spectral gamma-ray response is essentially indicative of the rock composition and is not sensitive to porosity; consequently, it can be used to discern the effect of changing clay mineralogy on the porosity curves (Fig. 4).

No dramatic changes in the $\mathrm{Th} / \mathrm{K}$ are observed between 0 and 385 mbsf, although the small variations in the $\mathrm{Th} / \mathrm{K}$ value would correspond to minor compositional changes (noticeable though, is the relative increase in the $\mathrm{Th} / \mathrm{K}$ value in the vicinity of a main thrust at $115-160 \mathrm{mbsf}$ ). As a result, the separation of the density-porosity and the neutron-porosity curves and the trends described above for the 0 385 interval would be mostly related to changes in the water content. The fact that the density porosity decreases more than the neutron po- rosity suggests that the observed trend is sensitive to a decrease in the free porosity, most likely resulting from compaction of the sediments.

Moderate changes in $\mathrm{Th} / \mathrm{K}$ value may also be observed between $385 \mathrm{mbsf}$ and the base of a main lithologic boundary of Unit II at 514 mbsf; (Shipley, Ogawa, Blum, et al., 1995). The general trend over this depth interval is a slight increase downwards. Zones with higher $\mathrm{Th} / \mathrm{K}$ values are recognizable between 498 and $514 \mathrm{mbsf}$. The general increase over the zone may be attributed to higher proportions of kaolinite and chlorite (Jurado and Alonso, Chapter 16, this volume; Underwood and Deng, Chapter 1, this volume). The corresponding increase in the calculated density porosity between 385 and $508 \mathrm{mbsf}$ might then be attributed in part to the application in the inversion of the wrong grain density for this depth interval, which is characterized as smectite-rich (Tribble, 1990; Brown and Ransom, 1996) at Site 671. Nevertheless, as discussed previously, regardless of the grain density employed, an increased porosity would be calculated for this interval. The increase in the apparent neutron porosity values, even if moderate, also suggests a higher water content, as porosity and bound water and/or interlayer water. These features are likely related to the velocity inversion within 100-200 $\mathrm{m}$ above the décollement observed by Moore et al. (Chapter 20, this volume).

The separation between density and neutron porosity curves below 514 mbsf (Unit III; Shipley, Ogawa, Blum, et al., 1995) is induced by a low density-porosity that results in a large separation between the porosity curves. This feature can be related to the relative increase in illite, kaolinite, and chlorite in the clays of the underthrust sequence (Underwood and Deng, Chapter 1, this volume; Jurado and Alonso, Chapter 16, this volume). The separation observed between 517 and 519 mbsf may be related to the local abundance of kaolinite and chlorite, which would result in a higher neutron porosity and lower density porosity.

Clays conduct electricity in two ways: through the pore water and through the clay grains. The presence of a negative surface charge allows clays to adsorb, primarily cations. The ability of a clay mineral 
Figure 4 . This page: Comparison between the porosity profiles (right) obtained from Hole 948A LWD density $\log$ (left) for different grain (matrix) densities. Facing page: Comparison between density and neutron porosity. Track 1 shows density porosity (grain density $=2.73$ ) and apparent neutron porosity, whereas track 2 shows the result of apparent neutron porosity minus density porosity, the $\mathrm{Th} / \mathrm{K}$ spectral ratio, and the resistivity profile.

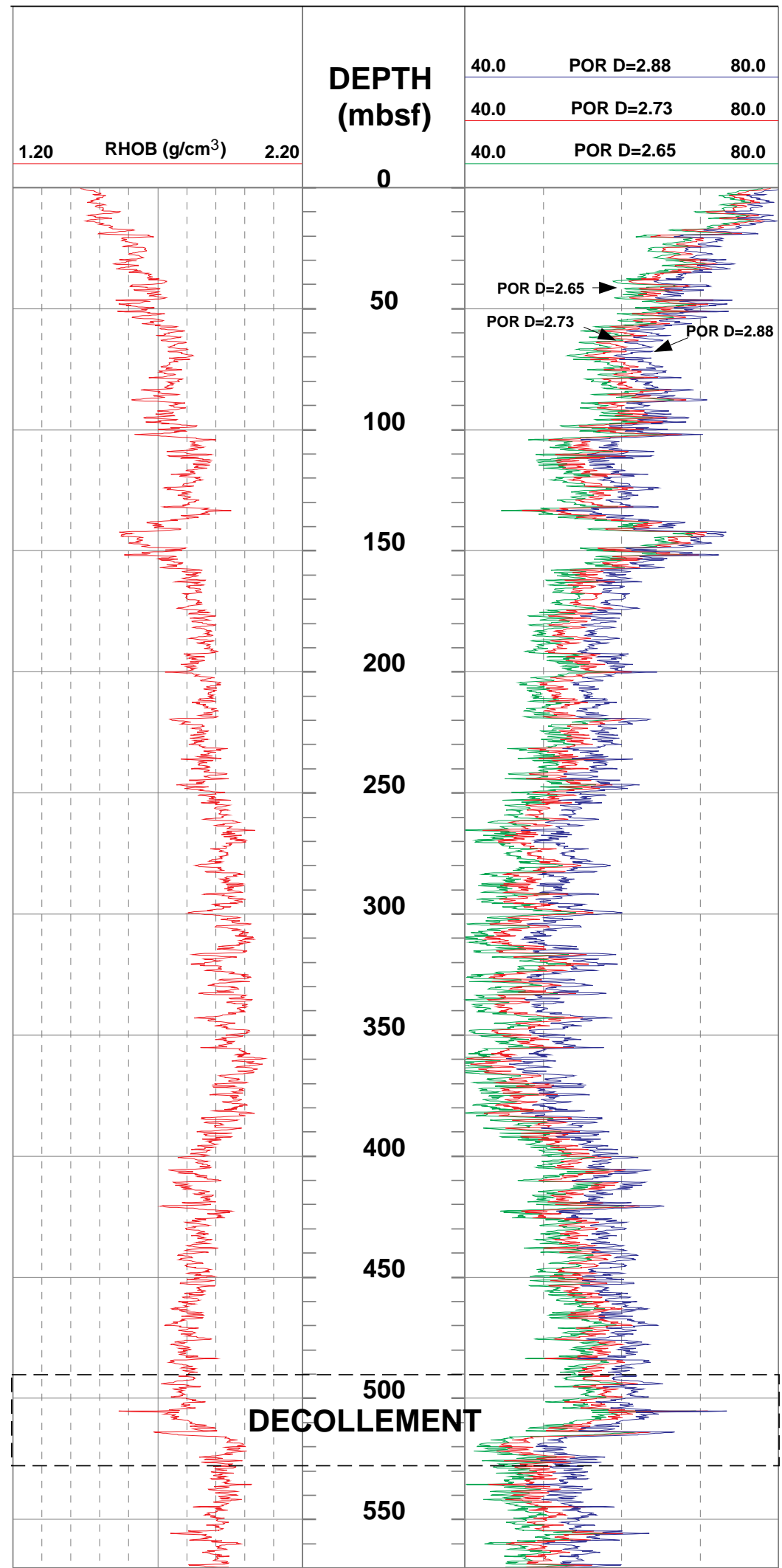




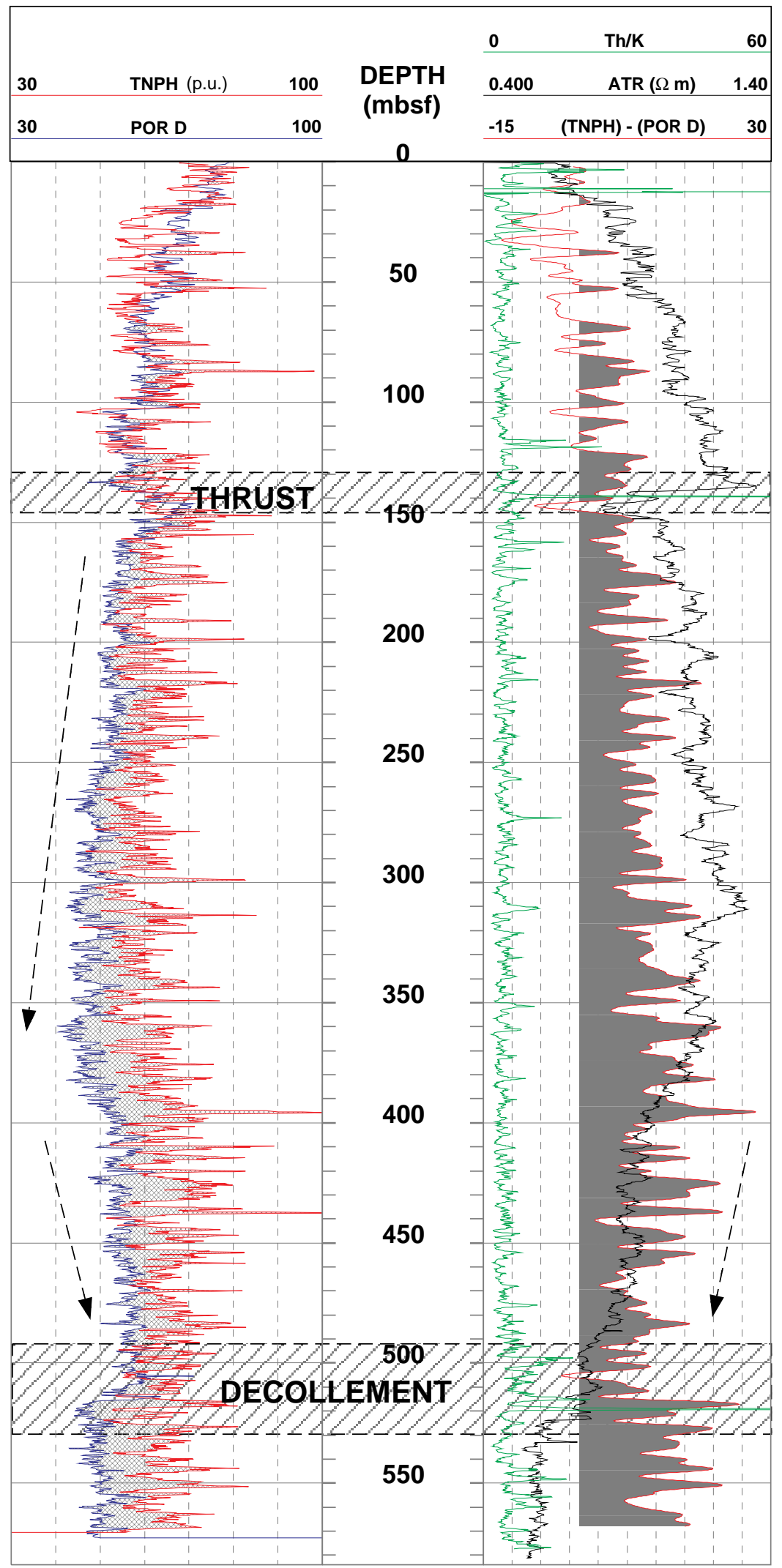

Figure 4 (continued). 
to form an electrical double layer with these ions is called the cation exchange capacity (CEC), which corresponds to the excess of cations over anions on the surface of a solid (Ellis, 1987). Henry (Chapter 10, this volume) has found a probable inverse correlation between the CEC and the sediment electrical conductivity on Hole 948C samples: lithologies with the highest smectite content (and highest CEC) have the lowest electrical conductivities at a given porosity. The resistivity curve (ATR) in Figure 4 shows a progressive decrease in resistivity for the depth interval 385-498 mbsf, which roughly mirrors the increase in density porosity (Fig. 4). This could indicate that the resistivity decrease is caused by pore and/or bound water in the sediments.

\section{Composition}

For the complex clay lithologies at Hole 948A, a simple model that uses inversion of mineralogy and porosity has been tested and calibrated against the mineralogy analyses on Hole 948C core samples (Jurado and Alonso, Chapter 16, this volume). This approach is based on the assumption that the log responses may be related directly to the sum of the proportions of the mineralogical components considered. Each component is multiplied by the appropriate response coefficients to develop a system of linear equations that can be solved simultaneously. Pore fluids were included as one component in so far as they participate in the log response. At each depth, the equations for each log take the form

$$
c_{11} v_{1}+c_{2} v_{2}+\ldots \ldots c_{n} v_{n}=L,
$$

where $n$ is the number of components, $v$ is the volume proportion of the component, $c$ is the $\log$ response of the component, and $L$ is the $\log$ response. Each log (SGR, RHOB, PEF, TNPH, and Th/K) provides a degree of freedom, with the mass-balance equation providing an additional equation. This matrix formulation is a linear model introduced by Savre (1963) and further developed by Burke et al. (1967). More extensive details on this methodology are given by Doveton (1994).

Compositional variables were defined according to core sample shore-based analyses (Underwood and Deng, Chapter 1, this volume; Jurado and Alonso, Chapter 16, this volume) and shipboard analyses (Fisher and Underwood, 1995) for quartz + plagioclase, smectite, illite, kaolinite, and chlorite. The LWD logs used in the matrix inversion include SGR, RHOB, PEF, TNPH, and Th/K. The averaged clay-type percentage computed in the inversion model (Fig. 5) agrees with the core-derived clay volumes and types to better than $5 \%$. The porosity determined in this inversion is approximately $30 \%$ on average lower than expected from the direct core, and density and neutron porosity values. However, recent studies on the porosity of smectiterich sediments (Brown and Ransom, 1996) have shown that both standard physical property and simple log inversion porosity determinations can greatly overestimate the true porosity of smectite-rich sediments. The authors performed corrections for more than $20 \%$ of the reported physical properties porosities of Site 671. In a comparative study on clay mineralogy and physical property variations at Hole 949B, W. Brückmann (pers. comm., 1996) concluded that the apparent correlation of porosity with zones of deformation at Hole 949B is most likely an artifact of the shipboard procedures for porosity measurement, which mistakenly interprets increased smectite content as higher porosity because free pore and interlayer water are not differentiated.

\section{COMPARISON OF LWD LOGS WITH CORE DATA}

The comparison between the LWD logs and the physical property core measurements establishes a correlation between independent observations in the investigation of the Northern Barbados accretionary prism. During Leg 156, only a short depth interval above and be- low the décollement zone was cored (Shipley, Ogawa, Blum, et al., 1995); however, a complete set of core measurements from a similar location was obtained during Leg 110 at Site 671 over the entire section and provides good reference data for comparison with the LWD logs (Mascle, Moore, et al., 1988).

\section{LWD Density vs. Core Density}

One of the first analyses performed on the LWD data was the comparison of the log-derived density with the core densities measured during Legs 156 (Hole 948C) and 110 (Hole 671B; Shipley, Ogawa, Blum, et al., 1995; J.C. Moore et al., 1995). Shipboard scientists demonstrated a good correlation between the LWD density and core-measured densities (Fig. 6).

\section{LWD Data vs. Core Thermal Conductivity}

The comparison between the Leg 110 and Leg 156 thermal conductivity core measurements shows that the Leg 156 thermal conductivity values are greater. A qualitative comparison with the LWD measurements shows that the gross features of the thermal conductivity profile mirror those of the density and resistivity logs. There are noticeable departures from this correlation between 100 and 140 mbsf and below 500 mbsf (Fig 7). Resistivity and density profiles are sensitive to porosity. The progressively increasing density and resistivity values observed in the first $100 \mathrm{~m}$ are the expression of a normal compaction trend in the sediments that results in a porosity decline. The increase in thermal conductivities observed between 0 and $100 \mathrm{mbsf}$ can also be related to the observed compaction trend (Fig. 7).

Significant variations in clay mineral composition are deduced from Holes 948C and 671B, where XRD sample analyses are available and are related to the relative smectite/illite abundance (Tribble, 1990; Underwood and Deng, Chapter 1, this volume; Jurado and Alonso, Chapter 16, this volume). Thermal conductivities for both minerals are very similar $(1.88 \mathrm{~W} /[\mathrm{m} \cdot \mathrm{K}]$ for smectite, $1.85 \mathrm{~W} /[\mathrm{m} \cdot \mathrm{K}]$ for illite and $1.85 \mathrm{~W} /[\mathrm{m} \cdot \mathrm{K}]$ for mixed layers; Brigaud, 1989), so changes in the relative composition of smectite-illite would not have a clear expression in the thermal conductivity. On the other hand, the increase in thermal conductivities at about $515 \mathrm{mbsf}$ can be related to the relative abundance in the samples of clay minerals that have higher thermal conductivities (kaolinite at $2.64 \mathrm{~W} /[\mathrm{m} \cdot \mathrm{K}]$ and/or chlorite at $3.26 \mathrm{~W} /[\mathrm{m} \cdot \mathrm{K}])$. The larger values observed below the décollement, within the underthrust sequence at about 540 mbsf, are most likely from carbonate-rich turbidite samples that were identified in the cores (Mascle, Moore, et al., 1988; Shipley, Ogawa, Blum, et al., 1995).

\section{LWD vs. Interstitial Water Chemistry}

A joint analysis of logging data and interstitial water analyses illustrates some correspondence among LWD density, resistivity, natural gamma spectral logs, and interstitial-fluid salinity. In Figure 8, a comparison of Hole 948C LWD density and the resistivity measurements shows that both measurements reproduce similar trends and features. The negative chloride anomalies derived from Holes 948C and $671 \mathrm{~B}$ pore-water geochemistry analyses represent fluid migration pathways, including the décollement zone and active thrusts (Mascle, Moore, et al., 1988; Shipley, Ogawa, Blum, et al., 1995). Figure 8 shows a correspondence of the distinct $\mathrm{Cl}$ minimum at 494 mbsf (Shipley, Ogawa, Blum, et al., 1995), which is located just above the structurally defined décollement in the Th/K profile (490519.8 mbsf; Housen et al, 1996; Shipley, Ogawa, Blum, et al., 1995).

The progressive decrease in resistivity observed between 450 and $495 \mathrm{mbsf}$ correlates with a progressive increase in the $\mathrm{Th} / \mathrm{K}$ value. In Figure 8, both curves have an inflection point at $495 \mathrm{mbsf}$, just below the inflection point in the interstitial water salinity profile. 


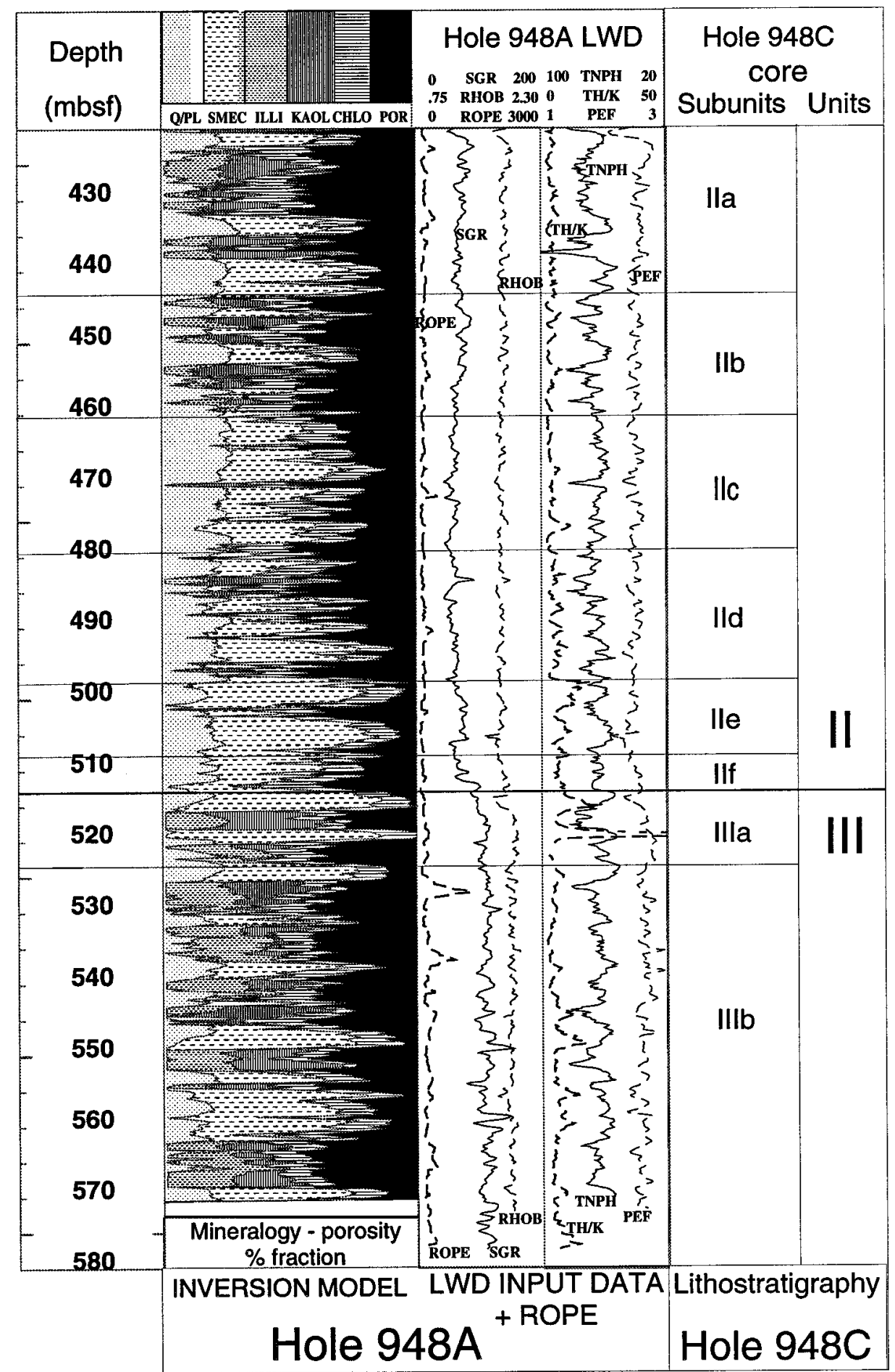

Figure 5. Mineralogy-porosity inversion model from Jurado and Alonso (Chapter 16, this volume).

\section{GEOLOGICAL INTERPRETATION AND CORE-LOG CORRELATION}

The comparison between the observed lithostratigraphy from Holes 948C and 671B and the LWD data from Hole 948A makes it possible to analyze how the LWD logs reflect the geological features. Shipboard analysis of Hole 948A LWD data allows for characterization of "log-lithologic" units, related to stratigraphic intervals of changing log properties that can be correlated with the lithostratigraphic units and subunits identified in the recovered core from Hole 948C (Shipley, Ogawa, Blum, et al., 1995). In Hole 948A, the Th/K profile shows two prominent spikes, at 139 and $519 \mathrm{mbsf}$. At these depths, the LWD logs show a minimum in K content. Comparison with the core data from Sites 671 and 948 shows a coincidence between those spikes and the base of the two main thrust faults: a thrust structure recognizable on seismic profiles (G.F. Moore et al., 1995) 


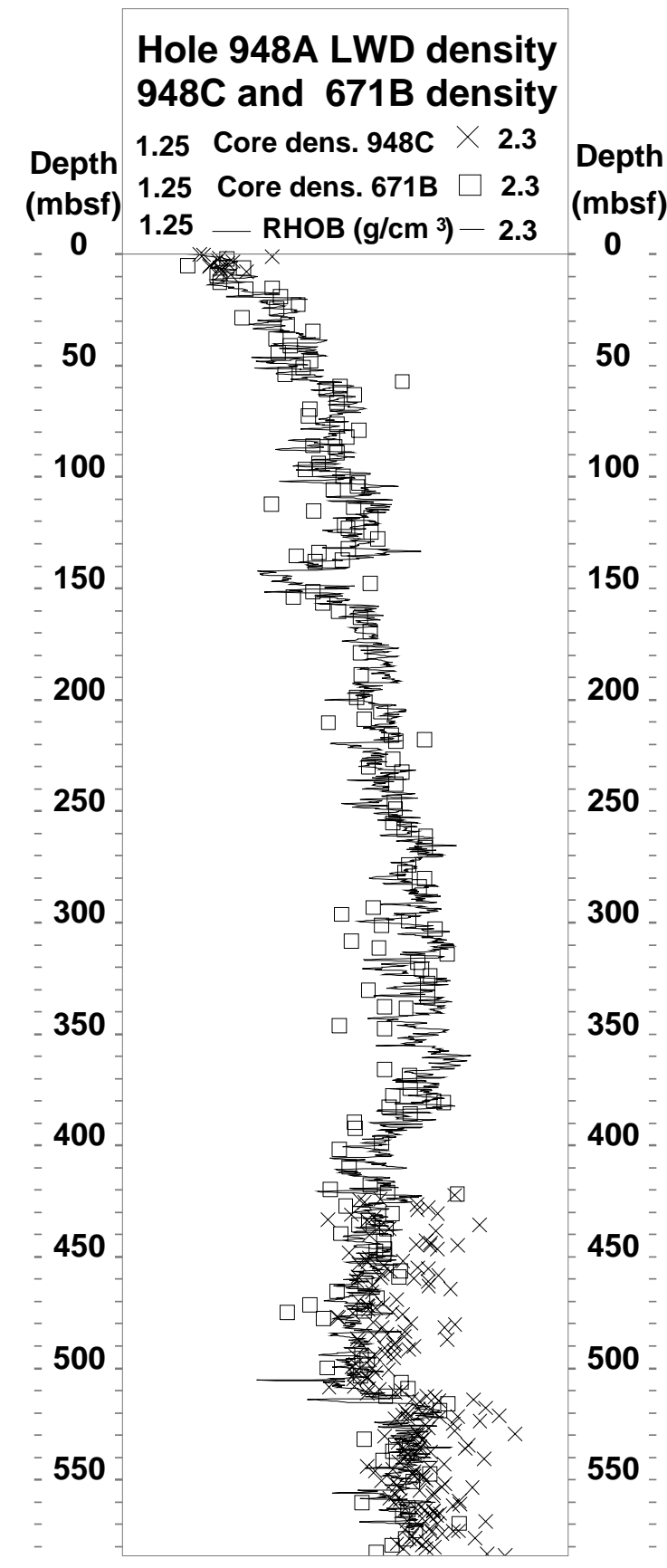

Figure 6. Measured core physical properties density of Holes $948 \mathrm{C}$ and 671B compared with the LWD density log acquired at Hole 948A.

and the décollement (Fig. 1). The average $\mathrm{Th} / \mathrm{K}$ value increases over depths ranging from $\sim 138$ to $160 \mathrm{mbsf}$ and from 498 to $519 \mathrm{mbsf}$, and can be related to changes in clay mineralogy in the fault zones. The faults are also detectable by abrupt changes in other log values (e.g., resistivity, density; Fig. 8). Without core recovery at Site 947, the geological structures may be identified from the log-lithologic units, assuming that the main changes in log response correspond to structural (mechanical) and sedimentary contacts in both holes.

Such an interpretation is consistent with the features highlighted by shaded bands in Figure 9. From this comparison, Hole 947A appears to reflect greater variation than Hole 948A. The log responses in Hole 948A remain relatively constant over large $(>100 \mathrm{~m})$ depth intervals, whereas in Hole 947A uniform log responses do not attain thicknesses greater than about $100 \mathrm{~m}$. Repeated reversal of normal compaction trends (decreasing porosity) occurs with depth in both holes and has been related to thrust faults within the prism (Saito and Goldberg, in press). Most of the shipboard interpreted "faults" are associated with changes in the $\mathrm{Th} / \mathrm{K}$ profile and would also indicate clay compositional changes associated with these faults. On the basis of comparison of the LWD profiles, the section at Site 947 appears to be more intensively faulted than at Site 948 . This also has been suggested in the seismic interpretation (G.F. Moore et al., 1995). The drill string became stuck in Hole 947A just above the décollement (520-535 mbsf), in a zone interpreted as a listric thrust rising off the décollement (Shipley, Ogawa, Blum, et al., 1995).

The integration of the core and logging results from Legs 156 and 110 shows consistency and agreement largely because most of the physical property measurements depend to a large degree on composition, porosity, or both. The mechanical contacts between faults that juxtapose sediments with different composition and porosity also have a distinct expression in the density, photoelectric effect, resistivity, natural gamma, and neutron logs. The association between the clay mineralogy and the faults as shown during previous legs, is particularly well expressed well by the $\mathrm{Th} / \mathrm{K}$ value.

\section{CONCLUSIONS}

The LWD measurements show good overall quality; only the natural gamma-ray spectral data are affected by high drilling rates, but they still may be used satisfactorily for qualitative and quantitative interpretation. The comparison between LWD and wireline log data at Site 948 shows that the quality of the wireline logs was strongly affected by the poor hole conditions (hole cavings and restrictions), particularly in the upper intervals of the prism and the décollement zone; they are not reliable. Porosity is one of the most important parameters in understanding the ongoing chemical and physical processes in the Barbados accretionary prism. LWD data acquired during ODP Leg 156 have provided critical and reliable information about porosity, chemistry, and geology as a continuous function of depth in the prism.

The LWD data reliably reflect the geological, petrophysical, and chemical changes at Sites 948 and 947. Porosity measurements in the clay-rich sediments of the Barbados accretionary prism are most likely biased by the clay mineral composition. The comparison between density-derived porosity and neutron-apparent porosity in these clayrich lithologies is useful in understanding the effect of clay minerals and the differentiation between pore and bound water vs. interlayer water. The types and volumes of minerals can be estimated by applying inversion techniques to the LWD data. A qualitative geologic lithostratigraphic and structural interpretation is feasible. A considerable potential exists to extract even more information from the logs about the petrophysical, geochemical, and geologic features in these clay-rich sediments.

\section{ACKNOWLEDGMENTS}

Logging-while-drilling data acquisition was funded by JOI/ USSAC and the U.S. National Science Foundation. The research of the first author was supported by a Spanish CICYT (AMB94-1410E) grant and a European Union HCM (ERB4001GT933623) grant. We are grateful also to those who enthusiastically participated in the successful acquisition of logging-while-drilling data for the first time in ODP. We acknowledge Warner Brückmann, Cheryl Schmitt, Dough Schmitt, Jane S. Tribble, and an anonymous reviewer for helpful revisions. 


\section{REFERENCES}

Brigaud, F., 1989. Conductivité thermique et champ de température dans les bassins sédimentaires à partir des données de puits, [Ph.D thesis]. Doc. et Trav. Centr. Geol. et Geoph. Montpellier, 23.

Brown, K., and Ransom, B., 1996. Porosity corrections for smectite rich sediments: impact on studies of compaction, fluid generation and tectonic history. Geology, 24:843-847.

Burke, J.A., Curtis, M.R., and Cox, J.T., 1967. Computer processing of log data enables better production in Chaveroo field. J. Pet. Tech., 19:889895.

Desbrandes, R., 1994. Data Acquisition and Processing While Drilling: Baton Rouge, LA (Louisiana State University, Dept. of Petroleum Engineering). (Syllabus)

Doveton, J.H., 1994. Geologic log analysis using computer methods. AAPG Computer Appl. in Geo., 2.

Ellis, D.V., 1987. Well Logging for Earth Scientists: New York (Elsevier).

Fisher, A.T., and Underwood, M.B., 1995. Calibration of an X-ray diffraction method to determine relative mineral abundances in bulk powders using matrix singular value decomposition: a test from the Barbados accretionary complex. In Shipley T.H., Ogawa Y., Blum, P., et al., Proc. ODP, Init. Repts., 156: College Station, TX (Ocean Drilling Program), 29-37.

Honda, H., and Magara, K., 1982. Estimation of irreducible water saturation and effective pore size of mudstones. J. Pet. Geol,. 4:407-418.

Housen, B., Tobin, H.J., Labaume, P., Maltman, A.J., Ashi, J., Blum, P., Brückmann, W., Fisher, A., Goldberg, D., Henry, P., Housen, B., Kastner, M., Laier, T., Leitch, E.C., Meyer, A., Moore, G.F., Moore, J.C, Ogawa, Y., Peacock, S., Rabaute, A., Shipley, T.H., Steiger, T.H., Underwood, M.B., Xu, Y., Yin, H., Zheng, Y, and Zwart, G., 1996. Strain decoupling across the décollement of the Barbados Accretionary Prism. Geology, 24:127-130.

Magara, K., 1979. Structured water and its significance in primary oil migration. Bull. Can. Pet. Geol., 27, 1:87-93.

Mascle, A., Moore, J.C., et al., 1988. Proc. ODP, Init. Repts., 110: College Station, TX (Ocean Drilling Program).

Moore, G.F., Zhao, Z., Shipley, T.H., Bangs, N., and Moore, J.C., 1995. Structural setting of the Leg 156 area, northern Barbados Ridge accretionary prism. In Shipley T.H., Ogawa, Y., Blum, P., et al., Proc. ODP, Init. Repts., 156: College Station, TX (Ocean Drilling Program), 13-27.

Moore, J.C., Mascle, A., Taylor E., Andreieff P., Alvarez P., Barnes, R., Beck, C., Behrmann, J., Blanc, G., Brown, K., Clark, M., Dolan, J.F., Fisher, A., Gieskes, J., Hounslow, M., McLellan, P., Moran, K., Ogawa, Y., Sakai, T., Schoonmaker, J., Vrolijk, P., Wilkens, R.H., and Williams,
C., 1988. Tectonics and hydrogeology of the northern Barbados Ridge: results from Ocean Drilling Program Leg 110. Geol. Soc. Am. Bull, 100:1578-1593.

Moore, J.C., Shipley, T.H., Goldberg, D., Ogawa, Y., Filice, F., Fisher, A., Jurado, M.-J., Moore, G.F., Rabaute, A., Yin, H., Zwart, G., and Brückmann, W., 1995. Abnormal fluid pressures and fault zone dilation in the Barbados accretionary prism: evidence from logging while drilling. Geology, 23:605-608.

Quirein, J.A., Baldwin, J.L., Terry, R.L., and Hendrieks, M., 1982. Estimation of clay types and volumes from well log data: an extension of the GLOBAL method. 22nd Annual SPWLA Log. Symp. Trans., pap. Q.

Rider M.H., 1986. The Geological Interpretation of Well Logs: London (Blackie/Halsted Press).

Ruhovets, N., and Fertl, W.H., 1981. Digital shaly sand analysis based on Waxman-Smits model and log-derived clay typing. 8th Eur. Well Logging Symp, SPWLA/SAID, V:107-134.

Saito, S., and Goldberg, D., 1997. Evolution of tectonic strain in the Barbados Accretionary Prism: estimates from logging-while-drilling. Earth Planet. Sci. Lett., 148:423-432.

Savre, W.C., 1963. Determination of a more accurate porosity and mineral composition in complex lithologies with the use of the sonic, neutron and density surveys. J. Pet. Tech., 15:945-959.

Serra, O., 1986. Advanced Interpretation of Wireline Logs: Houston (Schlumberger).

Schlumberger, 1983. Natural Gamma Ray Spectrometry: essentials of NGS interpretation: Houston (Schlumberger).

, 1987. Log Interpretation. Principles/Applications: Houston (Schlumberger).

Schlumberger Educational Services, 1992. Logging While Drilling: Houston (Schlumberger).

Shipley, T.H., Ogawa, Y., Blum, P., et al., 1995. Proc. ODP, Init. Repts., 156: College Station, TX (Ocean Drilling Program).

Tribble, J.S., 1990. Clay diagenesis in the Barbados accretionary complex: potential impact on hydrology and subduction dynamics. In Moore, J.C., Mascle, J., et al., Proc. ODP, Sci. Results., 110: College Station, TX (Ocean Drilling Program), 97-110.

Date of initial receipt: 4 September 1996

Date of acceptance: 20 December 1996

Ms 156SR-040 


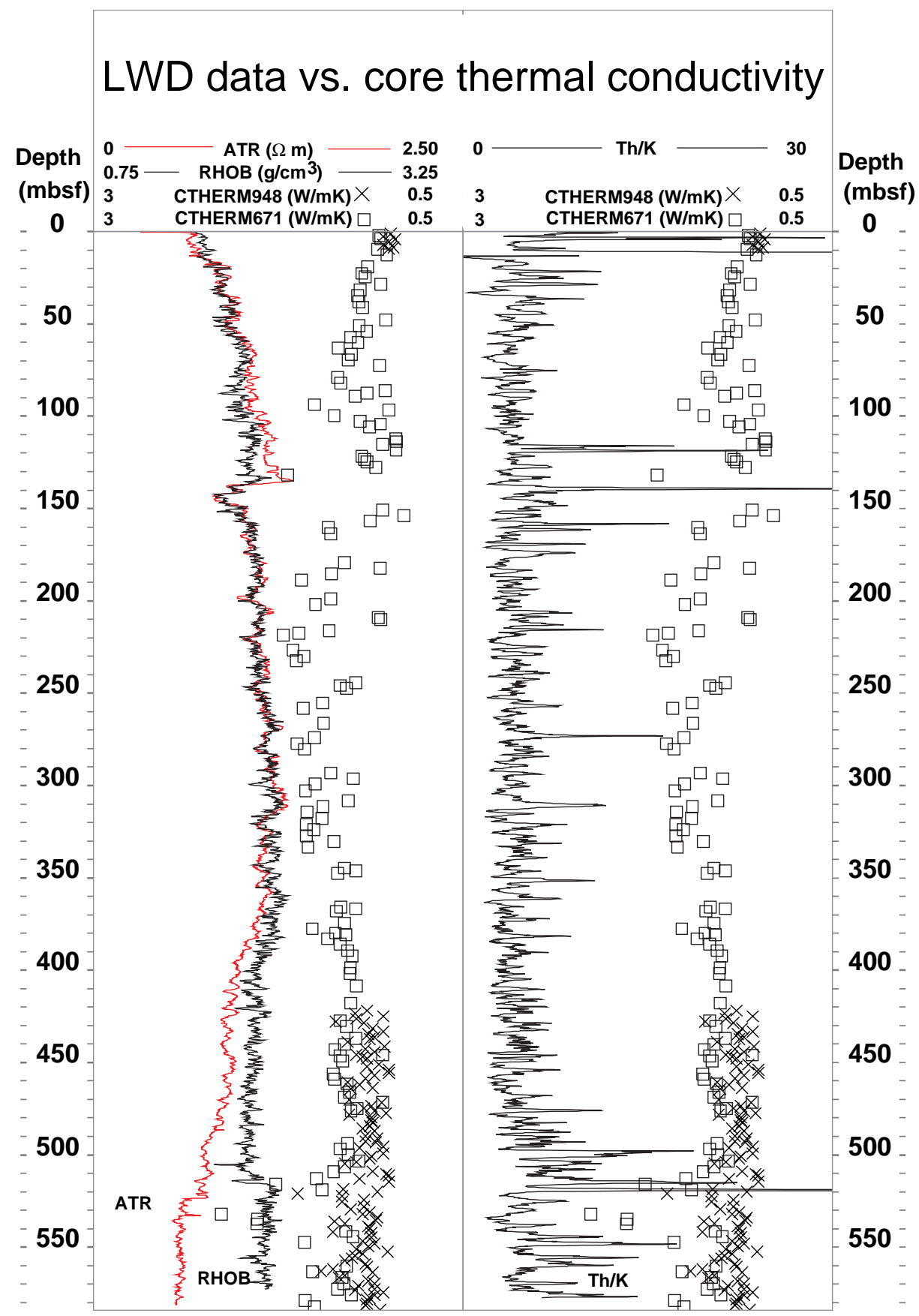

Figure 7. Measured thermal conductivities at Holes 948C and 671B compared with resistivity, density, and spectral natural gamma Th/K LWD logs. 


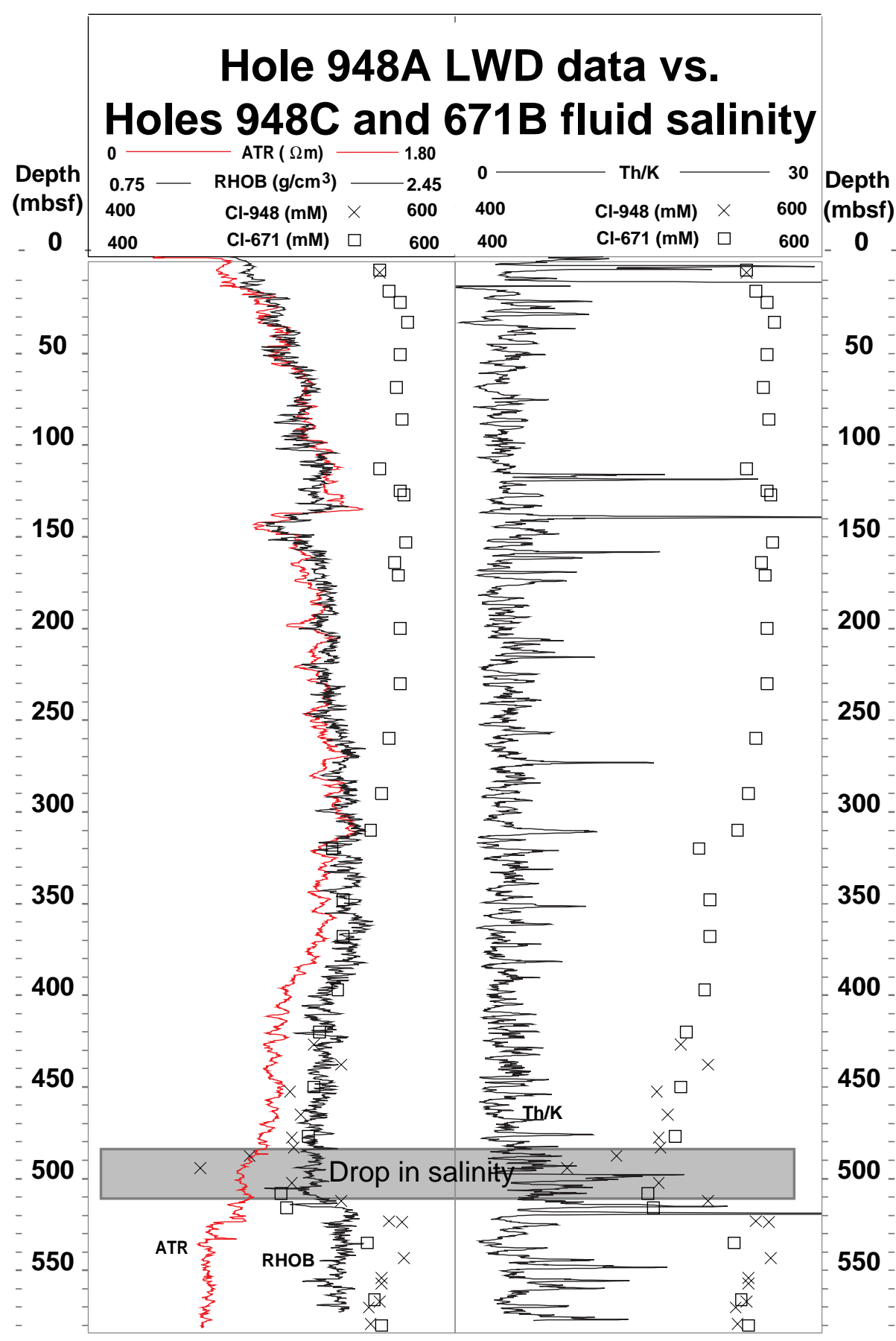

Figure 8. Site 671 and Site 948 concentration-depth profiles of dissolved chloride compared with the resistivity (ATR) and density (RHOB) logs on the left track and with the $\mathrm{Th} / \mathrm{K}$ profile on the right track. 


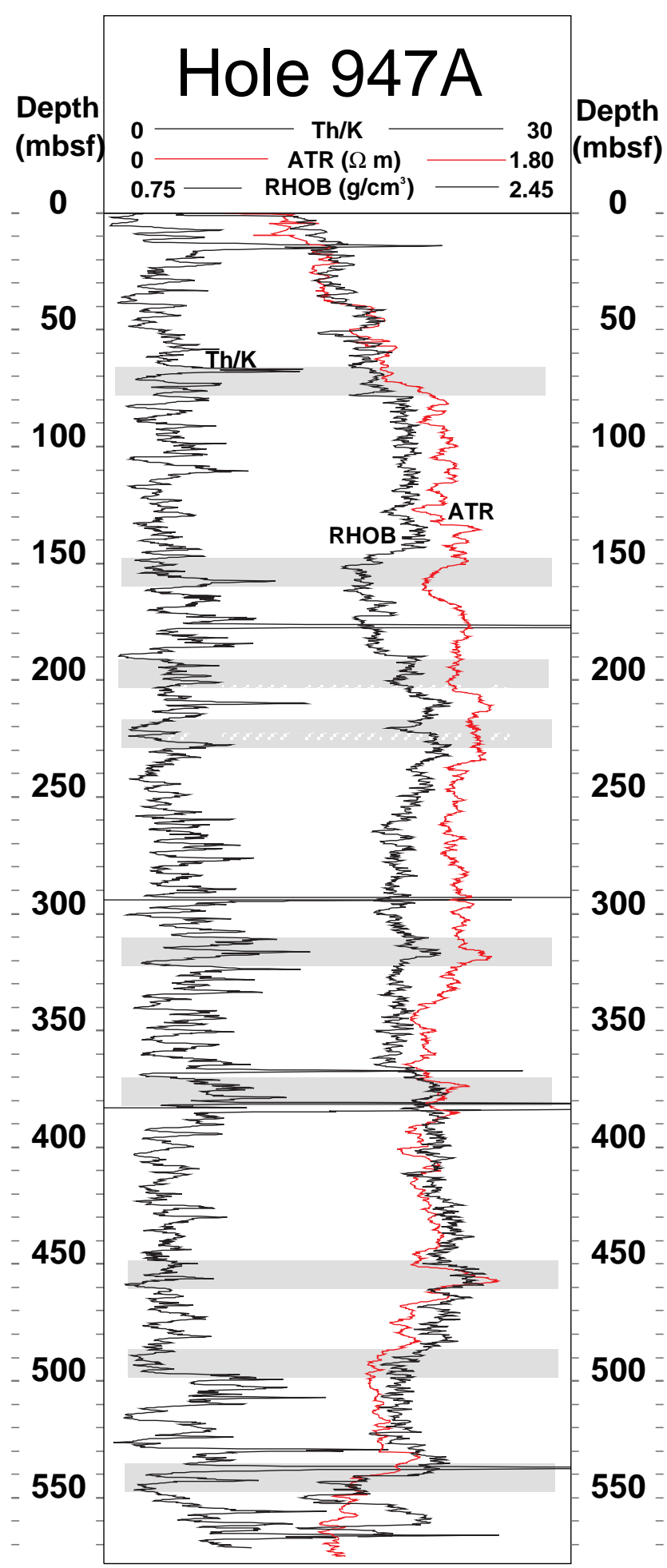

Figure 9. Hole 947A LWD Th/K, RHOB, and ATR profiles. The shaded bands indicate the location of abrupt changes in log values that could be related to faults. 